\title{
Drivers of compliance with international human rights treaties
}

Jacqueline Hicks

Institute of Development Studies

25 August 2021

\section{Question}

Is the ratification of international human rights treaties associated with better rights performance by signatory states? What drives compliance with international human rights treaties?

\section{Contents}

1. Summary

2. Rights in human rights treaties

3. Impact of treaty ratification

4. Drivers of compliance

5. References

The K4D helpdesk service provides brief summaries of current research, evidence, and lessons learned. Helpdesk reports are not rigorous or systematic reviews; they are intended to provide an introduction to the most important evidence related to a research question. They draw on a rapid deskbased review of published literature and consultation with subject specialists. 


\section{Summary}

As one scholar says, there is little doubt that international human rights treaties help some people some of the time (Hafner-Burton, 2009). The larger question is whether the level of gains that can be found empirically are sufficient to merit continued effort, which is a value judgement.

\section{Are international human rights treaties associated with better rights performance?}

- The appetite for a conclusive answer has driven a number of large scale quantitative studies that have broadly shown little or no effect, and sometimes even a backsliding. However, the headline conclusions belie much more complicated findings, and the research methods used are controversial. These issues undermine confidence in the findings.

- Comparative and individual case studies allow for more detailed information about how domestic human rights activists use international human rights laws in practice. They tend to be more positive about the effect of treaties, but they are not as systematic as the quantitative work.

- Some indirect measures of treaty effect show that the norms contained within them filter down into domestic constitutions, and that the process of human rights reporting at the UN may be useful if dialogue can be considered an a priori good.

\section{What drives states to comply with international human rights treaties?}

It is likely that states are driven to comply with human rights obligations through a combination of dynamic influences. Drivers of compliance with international law is a major, unresolved question in the research that is heavily influenced by the worldview of researchers.

The two strongest findings are:

- Domestic context drives compliance. In particular: (1) The strength of domestic nongovernmental organisations (NGOs), and links with international NGOs (INGOs), and (2) in partial and transitioning democracies where locals have a reason to use the treaties as tools to press their claims.

- External enforcement may help drive compliance when: (1) other states link human rights obligations in the treaties to preferential trade agreements, and (2) INGOs 'name and shame' human rights violations, possibly reducing inward investment flows from companies worried about their reputation.

Scholars also identify intermediate effects of continued dialogue and norm socialisation from the UN's human rights reporting processes. Interviews with diplomats involved in UN reporting say that the process is more effective when NGOs and individual governments are involved.

Evidence base: All of the evidence found came from academic research. As a major foundational question in the field of international law and international relations, there is a very large literature on the topic precisely because there are so many different ways to answer it. Within the limits of a rapid review, an attempt was made to cover the most cited articles which are emblematic of the different research approaches. Because results are so sensitive to the methods used, there is some attention to methodology, but space constraints do not allow full explanations. The evidence found did not address gender or disability issues. 


\section{What rights do international human rights treaties cover?}

The UN's Office of the High Commissioner for Human Rights (OHCHR) recognises nine core international human rights treaties (OHCHR, undated). Together they cover over 300 rights, including economic rights such as the right to work, pensions and housing (see Posner, 2014, p.151 for a full list of the rights covered in each treaty). They also cover many of the civil and political rights associated with "open societies," including:

- The right not to be discriminated against on the basis of race, sex, or ethnicity.

- Freedoms of expression, religion, association and peaceful assembly.

- Fair trials and protection from torture.

- The right to vote.

All UN Member States have ratified at least one core international human rights treaty, and 80 percent have ratified four or more (OHCHR, undated). Some of the rights appear repeatedly in several of the treaties.

\section{Do treaties lead to better human rights in practice?}

\section{There are many difficulties to answering this seemingly straightforward question.}

- The absence of counterfactuals: One of the fundamental difficulties with determining whether international legal regimes affect state behaviour is being able to pose a convincing counterfactual...to demonstrate that a compliant state would have exhibited a lower level of compliance had it not ratified the treaty in question (Hill, 2010).

- Human rights may conflict with each other: Posner (2014) notes that: laws that improve judicial procedure and give greater protections to defendants might cause police to use extra-judicial methods - torture, harassment, killings - to maintain order, so while human rights improvements will be seen in one area, the net effect may be nil or even negative. Similarly, a law that provides greater health services to women might result in fewer funds for schools.

- Causal inference is unrealistic: Scholars of international human rights law still regularly debate whether the major international agreements have had any effect on state behaviour. Part of the reason that this threshold question is still contested is that there are a number of barriers to causal inference that make answering it with observational data incredibly difficult (Chilton, 2017).

- Measures of human rights are controversial: There are measurement problems from scarce sources of uniform information and reliable data across the global set of states. Typically, scholars must choose between rather thin measures of human rights, usually limited to individual rights and freedoms, or richer qualitative measures that do not allow as much empirical rigour (Keith, 2010).

- It may be the wrong question: In a review of the literature, Moyn (2018) contends that there is not much difference between scholars who argue for and against treaties with 
their empirical results - both show some effects on human rights practices. He says that what would really settle the dispute is a theory of what counts as sufficient progress, and this is not something empiricism could ever provide.

\section{Several large-scale quantitative studies show that ratification does not improve human rights.}

In a first large-scale quantitative study, Keith (1999) tested whether ratification of the International Covenant on Civil and Political Rights (ICCPR) affected civil and political rights as measured by the Freedom House index in 178 countries. In a first bivariate test of differences of means, she found "statistically significant differences between the behavior of states parties and the behavior of non-party states" (p.95). However, in further different tests, she found no statistically significant influence of ICCPR ratification, and concludes that "it may be overly optimistic to expect that being a party to this international covenant will produce an observable direct impact" (p.95).

Hathaway's (2002) much cited work (2371 citations ${ }^{1}$ ) contains "more comprehensive methods" than Keith's (Neumayer, 2005, p.933). To measure human rights practices, she takes scores on genocide from the U.S. State Failure Task Force Project and the civil liberty index from Freedom House. She also codes her own measures of torture and fair trial from U.S. state data. She measures women's political rights by the percentage of men in each country's legislature. She then tests their relationship with the adoption of several treaties: the Genocide Convention, the ICCPR, the Torture Convention, and the Convention on the Political Rights of Women, and a number of regional human rights treaties.

Comparing the average human rights score of countries that have ratified the treaties with those that have not, she finds that ratifying countries typically have a better record than nonratifying ones. However, further, different tests find no evidence that ratification of international human rights treaties is systematically associated with better human rights performance. In some cases, she finds that ratification is associated with worse performance (Neumayer, 2005).

Hafner-Burton and Tsutsui (2005) quantify data from the U.S. state department and Amnesty International, to test the relationship to treaty adoption using a different statistical model to Hathaway. The authors conclude that: "there is no systematic evidence to suggest that ratification of human rights treaties in the UN system itself improves human rights practices." However, the authors also state that: "the growing legitimacy of human rights ideas in international society, which the legal regime helped establish, provides much leverage for nongovernmental actors to pressure rights-violating governments to change their behavior." (p.1401).

${ }^{1}$ All citation counts in this rapid review are taken from Google Scholar. 


\section{The methods used in these quantitative studies are frequently criticised.}

The authors of these large-scale quantitative studies are careful to lay out their statistical models and data sources in all their complexity, as well as conflicting findings. However, later citations of these studies frequently present them simplistically as proof that human rights treaties do not affect human rights practices.

Simmons (2010) criticises these studies for methodological weaknesses (p.289). On Hathaway's research, she makes three main criticisms: (1) on the assumption that the more treaties a country ratifies, the higher the expected commitment to human rights (2) it is suspect to treat ratification as an exogenous variable -"it can hardly be the case that states randomly sort into ratifiers and nonratifiers" (p.290), and (3) "the studies were designed only to detect homogenous effects across all states alike. Despite acknowledging a complex social and political world, the treaties are modelled as unmediated and their effects unconditional. Practically no one who has done qualitative work in this area imagines such a determinative or direct mechanism. Rather, they see treaties as tools for strategic or normatively driven actors to change the politics of human rights compliance in specific institutional contexts" (p.290).

Neumayer (2005) also criticises the methods used by Hafner-Burton and Tsutsui (2005), and Keith (1999). Hill (2010, p.1162) further criticises elements of the statistical models used in such research. Keith (2010, p.15/26 pdf) states "weak confidence" in the literature that fails to find an association of better human rights with treaty commitment due to their neglect of methods to "operationalize and test the underlying assumptions that would predict no effect."

\section{Some research highlights gains in human rights practices related to human rights laws.}

Using mixed qualitative and quantitative methods, another highly cited work by Simmons (2009, 2304 citations) shows that treaties have made an important positive difference in terms of respect for human rights, particularly in partially democratic and transitional countries (Shawki, 2010). However, the methods, assumptions and analysis in Simmons' book were also questioned by a self-proclaimed sceptic of human rights treaties, Posner (2012).

Qualitative case studies use fieldwork research of activists around the world to show how they make use of human rights treaties. Merry (2006) presents case studies from India, Hong Kong, Hawaii, and Fiji to record some of the ways that local human rights activists "appropriate and enact" international human rights law. Similarly, Risse et al (1999; 2013 - 4136 citations) edited two volumes of research from a large selection of countries which detail the ways in which international human rights laws are "reinforced by transnational and domestic advocacy", often leading to improvements in human rights practices.

\section{There is evidence that state parties to human rights treaties incorporate some of those rights into their national constitutions.}

Ginsburg et al. (2013, p.61) use a comprehensive database on the contents of the world's constitutions to show that "international rights documents, starting with the Universal Declaration of Human Rights, have shaped the rights menu of national constitutions in powerful ways." The 
authors conclude that their research "confirms the complementary relationship between treaty ratification and domestic constitutional norms, and suggests that one important channel of treaty efficacy may be through domestic constitutions."

However, Posner (2014, p.77) points out that "many of those countries do not in fact respect the rights in their own constitutions."

\section{Other research focuses on the internal UN processes of treaty enforcement, and finds that they have small, positive effects.}

Creamer and Simmons (2018, p.31-32) explain that: "All major UN human rights treaties have established bodies of experts to oversee treaty implementation. States parties are obligated to self-report to these bodies of putative experts. Critics uniformly point out that these bodies cannot enforce their recommendations. This is true. However, it does not necessarily follow that they are useless or without effect."

Focusing on the Convention on the Elimination of Discrimination against Women (CEDAW), Creamer and Simmons (2018) use quantitative analysis to compare report submission to CEDAW's implementing bodies by 188 countries with women's rights as measured by a women's political empowerment and fundamental civil rights index developed by the Varieties of Democracy project. They find that "periodic review under CEDAW has continuous, albeit small, positive effects on women's rights attributable to the cumulative reporting cycle" (p.52).

The authors suggest that "treaty ratification initiates an iterative and ongoing 'constructive dialogue' between a government and the international human rights regime about progress - or lack thereof - on treaty implementation" (p.33), and that "the international community should not think of self-reporting as a hard enforcement mechanism, but rather as an opportunity for domestic stakeholders to mold their own futures in the shadow of international law" (p.34).

\section{What drives compliance?}

\section{The reasons why states comply with international law is a major, and unresolved question in the literature.}

Known as the "compliance debate", Scharf (2009, p.50) says that explaining why states comply with any type of international law "has been debated since ancient times and remains one of the most contested questions in international relations."

Compared with other types of international law, it is widely recognised that explaining state compliance with human rights treaties is particularly puzzling. Simmons (2009) notes that human rights regimes do not involve reciprocal compliance, as is the case with trade agreements. If one party does not respect a trade agreement, then it risks the other party retaliating by also withdrawing. This basic mechanism of reciprocal compliance is not at play in human rights agreements because one state's failure to respect the rights of its citizens cannot be corrected by another state reciprocally violating the rights of its own citizens (Chilton, 2017). 
Because explaining compliance with human rights treaties cannot rely on the fundamental mechanism of reciprocal compliance, the task is heavily influenced by theory. Simmons $(2010$, p.275) notes that "long-standing theoretical traditions continue to inform research." In other words, a researcher's worldview influences what types of research they undertake, which influences the type of empirical results found. There are a number of ways to describe the theoretical traditions that inform research in this area, Simmons $(2009$, p.275) notes at least nine. Carraro (2019) summarises them down to three in Table 1 below.

Table 1: How different approaches understand drivers of compliance

\begin{tabular}{ll}
\hline Name of Approach & Drivers of compliance \\
\hline Enforcement & $\begin{array}{l}\text { Actions that generate pressure on states to submit accurate and } \\
\text { timely reports, or to follow-up recommendations. Could include } \\
\text { pressure from states or the broader public. Can induce compliance } \\
\text { through fear of material or reputational losses. }\end{array}$ \\
\hline Constructivist & $\begin{array}{l}\text { Processes that trigger learning. Reporting on human rights is viewed } \\
\text { as a nonconfrontational mechanism where the focus is on stimulating } \\
\text { learning, and socializing states to the "right" approach in dealing with } \\
\text { human rights norms. }\end{array}$ \\
\hline Managerial & $\begin{array}{l}\text { Delivering practically feasible recommendations. Here, rule ambiguity } \\
\text { is considered to be one of the most likely culprits of poor rule } \\
\text { implementation. }\end{array}$ \\
\hline
\end{tabular}

Source: Summarized from Carraro (2019, p.1082) under CC BY.

These potential drivers are not mutually exclusive. Their value lies in offering a way to understand the different empirical results as detailed below.

\section{Many scholars highlight the importance of domestic civil society pressure to explain compliance.}

Neumayer (2005) conducted a large-scale quantitative analysis of countries to ask: Do international human rights treaties improve respect for human rights? He includes variables to measure the strength of civil society and regime type. He states that "ratification is more beneficial the stronger a country's civil society, that is, the more its citizens participate in international NGOs" (p.950). He concludes that in most cases, for treaty ratification to work, there must be conditions for domestic groups, parties, and individuals and for civil society to persuade, convince, and perhaps pressure governments into translating the formal promise of better human rights protection into actual reality.

Summarising her own research findings from her 2009 book, Simmons (2010, p.291): "argues that in stable autocracies, citizens have no means to mobilize without being crushed. In stable democracies, where rights are well protected, they have no real motive to mobilize. Treaties become useful tools in those cases in which locals have a reason to use them strategically to press their claims: in partial and transitioning democracies. Simmons' results show that certain rights, such as protections against torture, are correlated with treaty 
ratification in this middle category of countries, but not in stable democracies or autocracies."

In a study of the reporting process under UN human rights treaties, Krommendijk (2015, p.194) concludes that: "While factors related to the defective design and limited legitimacy of the treaty body system inhibit the effectiveness of the recommendations, several domestic factors have at times positively affected the recommendations' effectiveness, particularly the mobilisation of domestic actors."

In a review of the literature, Keith (2010) characterises the research of both Hafner-Burton and Tsutsui (2005), and Powell and Staton (2009) as providing evidence that "as the number of INGOs to which citizens belong increases, the level of protection of human rights increases" (p.17/26 pdf).

\section{Other research finds that compliance is driven by domestic regime type, judicial effectiveness, and national security interests.}

Powell and Staton (2009) find that as the effectiveness of the domestic judiciary increases, the joint probability of ratifying the CAT in full and then violating the treaty decreases. According to Keith (2010) they only find mixed evidence that the joint probability of not ratifying and torturing increases with an effective judiciary in place.

On regime type, Neumayer (2005, p.950) finds that "treaty ratification often becomes more beneficial to human rights the more democratic the country is."

Cardenas (2007) includes national security into her qualitative book length study on compliance. According to Simmons (2010), she finds that the more national security seems to be at stake, and the stronger "pro-violation constituencies" are within a country, the more likely that country is to violate human rights treaties and try disingenuously to appear to comply with their obligations.

\section{Preferential trade agreements are one external enforcement option that may help drive compliance.}

Hafner-Burton (2005) tests her hypothesis that preferential trade agreements (PTAs) help drive state compliance with human rights law through case studies and developing a statistical model to apply to 177 countries. She claims that "PTAs are more effective than softer human rights agreements in changing repressive behaviors. PTAs improve members' human rights through coercion, by supplying the instruments and resources to change actors' incentives to promote reforms that would not otherwise be implemented" (p.593). However, she concludes that "International institutions have the greatest influence over state compliance with human rights principles when they offer substantial gains with some kind of coercive incentives" (p.624).

\section{There is evidence that 'naming and shaming' directly and indirectly drives compliance.}

Matanock (2020) summarises the literature on naming and shaming, noting that most research finds that naming and shaming generally supports human rights (DeMeritt 2012, Franklin 
2008, Hendrix and Wong 2013, Krain 2012). He highlights one exception: Hafner-Burton (2008).

Hafner-Burton's (2008) data on shaming came from Amnesty International reports, Economist and Newsweek reports, and United Nations Commission on Human Rights resolutions condemning human rights abuses. She tested for relationships with three indexes on repression, adding other variables on domestic context such as level of democracy, GDP, population and others. Testing her data for 145 countries from 1975 to 2000, she concludes that "governments put in the spotlight for abuses continue or even ramp up some violations afterward, while reducing others" (p.689).

Matanock (2020) also highlights research where the naming and shaming serves as a monitoring device that then induces some other type of punishment. For example, Barry et al. (2013) use similar large-number empirical quantitative techniques to Hafner-Burton, but with different data sources for shaming from a database that records the number of times in a year that Reuters reported shaming directed at a state by one of 432 human rights INGOs. The authors then test against foreign direct investment inflows to a country. Their results demonstrate that INGO shaming exerts a robust negative effect on foreign investment flows into the shamed state, indicating that multi-national corporations are indeed sensitive to the reputational costs that may be incurred through business dealings with states whose repressive practices have been actively publicised.

Peterson et al. (2016) have a similar approach to studying the effect of naming and shaming on a country's exports. They find that human rights abuse alone is insufficient to damage a state's exports. However, as attention to abuse increases via human rights organisations shaming, abuse has an increasingly negative impact on exports. He adds that there is no effect of shaming when importers are similarly abusive.

Using a data set of bilateral foreign aid to 118 developing countries between 1981 and 2004, Murdie and Peksen (2014) investigate the circumstances under which foreign aid donors apply aid sanctions to punish repressive states. They find that aid sanctions typically occur when repressive states do not have close political ties to donors, when violations have negative consequences for donors and when violations are widely publicised. In other words, naming and shaming increases the likelihood of aid sanctions on repressive states.

Lebovic and Voeten (2009) show the connection between World Bank aid sanctions and United Nations Commission on Human Rights resolutions condemning a country's human rights record.

The literature on the effects of naming and shaming on human rights is very large, not all aspects could be covered in this rapid review.

\section{Some research notes the importance of political pressure, NGO involvement, and elite socialisation within the UN's internal reporting procedures.}

Carraro (2019) looks at the extent to which two United Nations human rights mechanisms - the Universal Periodic Review (UPR) and the state reporting procedure of the treaty bodies-are perceived as capable of stimulating compliance with human rights. The author conducted 40 
semi-structured interviews and an online survey with diplomats and experts who are directly involved in these two mechanisms.

The study finds that, according to the interviewees, the UPR more effectively drives compliance because it allows the active involvement of NGOs in the process, and because recommendations for human rights improvements come from individual countries rather than experts: "Recommendations in the UPR are not endorsed by all UN states participating in the review, but are exclusively attributed to the country issuing them. Hence, they take the form of bilateral recommendations, which has strong political implications: accepted UPR recommendations become political commitments between countries" (Carraro, 2019, p.1090).

However, taking a 'constructivist approach' whereby state elites are thought to change human rights practices through a process of learning, Creamer and Simmons (2019, p.31) find the "respectful posture toward states parties, using diplomatic and increasingly technical language" in treaty bodies to be more useful than harsh excoriation which is likely to lead to backlash. Based on the authors' own observations, they identify four mechanisms within UN reporting procedures which drive compliance:

- Elite socialisation

- Learning and capacity building

- Domestic mobilisation

- Law development

The authors nevertheless recognise the weaknesses of UN reporting, and that the processes they identify "exist synergistically with a multitude of other influences" (p.3).

\section{References}

Carraro, V. (2019). Promoting Compliance with Human Rights: The Performance of the United Nations' Universal Periodic Review and Treaty Bodies. International Studies Quarterly, 63(4), 1079-1093. doi:10.1093/isq/sqz078

Chilton, A. (2017). Experimentally Testing the Effectiveness of Human Rights Treaties. Chicago Journal of International Law, 18(1), Article 4. https://chicagounbound.uchicago.edu/cjil/vol18/iss1/4

Creamer, C., \& Simmons, B. (2018). The Dynamic Impact of Periodic Review on Women's Rights. Law and Contemporary Problems, 81(4), 31-72. https://heinonline.org/HOL/Page?collection=journals\&handle=hein.journals/lcp81\&id=790\& men_tab=srchresults

Creamer, C., \& Simmons, A. (2019). The Proof is in the Process: Self-Reporting under International Human Rights Treaties. American Journal of International Law, 114(1), 1-50. doi:10.1017/ajil.2019.70

Franklin, J. (2008). Shame on You: The Impact of Human Rights Criticism on Political Repression in Latin America. International Studies Quarterly, 52(1), 187-211. doi:10.1111/j.1468-2478.2007.00496.x

Ginsburg, T., Elkins, Z. \& Simmons, B. (2013). Getting to Rights: Treaty Ratification, Constitutional Convergence, and Human Rights Practice. Harvard International Law Journal, 61. 
https://chicagounbound.uchicago.edu/cgi/viewcontent.cgi?article=5005\&context=journal_ar ticles

Hafner-Burton, E. M. (2005). Trading Human Rights: How Preferential Trade Agreements Influence Government Repression. International Organization, 59(3), 593-629.

doi:10.1017/s0020818305050216

Hafner-Burton, E. M. (2008). Sticks and Stones: Naming and Shaming the Human Rights Enforcement Problem. International Organization, 62(4), 689-716. doi:10.1017/s0020818308080247

Hafner-Burton, E. M., \& Ron, J. (2009). Seeing Double: Human Rights Impact through Qualitative and Quantitative Eyes. World Politics, 61(2), 360-401. doi:10.1017/s0043887109000136

Hafner-Burton, E. M., \& Tsutsui, K. (2005). Human Rights in a Globalizing World: The Paradox of Empty Promises. American Journal of Sociology, 110(5), 1373-1411. doi:10.1086/428442

Hathaway, O. A. (2002). Do Human Rights Treaties Make a Difference? The Yale Law Journal, 111(8), 1935. doi:10.2307/797642

Hendrix, C. S., \& Wong, W. H. (2012). When is the Pen Truly Mighty? Regime Type and the Efficacy of Naming and Shaming in Curbing Human Rights Abuses. British Journal of Political Science, 43(3), 651-672. doi:10.1017/s0007123412000488

Hill, D. W. (2010). Estimating the Effects of Human Rights Treaties on State Behavior. The Journal of Politics, 72(4), 1161-1174. doi:10.1017/s0022381610000599

Keith, L. C. (1999). The United Nations International Covenant on Civil and Political Rights: Does it Make a Difference in Human Rights Behavior? Journal of Peace Research, 36(1), 95118. doi:10.1177/0022343399036001006

Keith, L. C. (2010). Human Rights Instruments. Oxford Handbooks Online. doi:10.1093/oxfordhb/9780199542475.013.0016

Krain, M. (2012). J'accuse! Does Naming and Shaming Perpetrators Reduce the Severity of Genocides or Politicides? International Studies Quarterly, 56(3), 574-589. doi:10.1111/j.1468-2478.2012.00732.x

Krommendijk, J. (2015). The (In)effectiveness of UN Human Rights Treaty Body Recommendations. Netherlands Quarterly of Human Rights, 33(2), 194-223. doi:10.1177/016934411503300205

Lebovic, J. H., \& Voeten, E. (2009). The Cost of Shame: International Organizations and Foreign Aid in the Punishing of Human Rights Violators. Journal of Peace Research, 46(1), 79-97. doi:10.1177/0022343308098405

Matanock, A. M. (2020). How International Actors Help Enforce Domestic Deals. Annual Review of Political Science, 23(1), 357-383. doi:10.1146/annurev-polisci-050718-033504

Merry, S. E. (2005). Human Rights and Gender Violence. doi:10.7208/chicago/9780226520759.001.0001

Moyn, S. (2018). Beyond the Human Rights Measurement Controversy. Law and Contemporary Problems, 81, 121-137.

https://scholarship.law.duke.edu/lcp/vol81/iss4/6 
Murdie, A., \& Peksen, D. (2014). The Impact of Human Rights INGO Shaming on Humanitarian Interventions. The Journal of Politics, 76(1), 215-228. doi:10.1017/s0022381613001242

Neumayer, E. (2005). Do International Human Rights Treaties Improve Respect for Human Rights? Journal of Conflict Resolution, 49(6), 925-953. doi:10.1177/0022002705281667

$\mathrm{OHCHR}$ (Office of the High Commissioner for Human Rights). (undated). Human Rights Bodies. https://www.ohchr.org/EN/HRBodies/Pages/HumanRightsBodies.aspx

Peterson, T. M., Murdie, A., \& Asal, V. (2016). Human Rights, NGO Shaming and the Exports of Abusive States. British Journal of Political Science, 48(3), 767-786. doi:10.1017/s0007123416000065

Posner, E. (2012). Some Skeptical Comments on Beth Simmons's Mobilizing for Human Rights. New York University Journal of International Law and Politics, 44, 819. https://nyujilp.org/wp-content/uploads/2010/06/44-3_Posner_Web.pdf

Posner, E. (2014). The Twilight of Human Rights Law. Oxford University Press.

Powell, E. J., \& Staton, J. K. (2009). Domestic Judicial Institutions and Human Rights Treaty Violation. International Studies Quarterly, 53(1), 149-174. doi:10.1111/j.14682478.2008.01527.x

Risse, T., Ropp, S. C., \& Sikkink, K. (Eds.). (1999). The Power of Human Rights: International Norms and Domestic Change. Cambridge University Press.

Risse, T., Ropp, S. C., \& Sikkink, K. (Eds.). (2013). The Persistent Power of Human Rights. doi:10.1017/cbo9781139237161

Scharf, M. (2009). International Law in Crisis: A Qualitative Empirical Contribution to the Compliance Debate. Faculty Publications. 575.

https://scholarlycommons.law.case.edu/faculty_publications/575

Shawki, N. (2010). Mobilizing for Human Rights. International Law in Domestic Politics. The Journal of Politics, 72(4), 1259-1261. doi:10.1017/s0022381610000757

Simmons, B. (2009). Mobilizing for Human Rights. doi:10.1017/cbo9780511811340

Simmons, B. (2010). Treaty Compliance and Violation. Annual Review of Political Science, 13(1), 273-296. doi:10.1146/annurev.polisci.12.040907.132713

\section{Suggested citation}

Hicks, J. (2021). Drivers of compliance with international human rights treaties. K4D Helpdesk Report No. 1039 Institute of Development Studies. DOI:10.19088/K4D.2021.130.

\section{About this report}

This report is based on six days of desk-based research. The K4D research helpdesk provides rapid syntheses of a selection of recent relevant literature and international expert thinking in response to specific questions relating to international development. For any enquiries, contact helpdesk@k4d.info.

K4D services are provided by a consortium of leading organisations working in international development, led by the Institute of Development Studies (IDS), with the Education Development Trust, Itad, University of Leeds Nuffield Centre for International Health and Development, Liverpool School of Tropical Medicine (LSTM), University of Birmingham International Development Department (IDD) and the University of Manchester Humanitarian and Conflict Response Institute (HCRI). 
This report was prepared for the UK Government's Foreign, Commonwealth \& Development Office (FCDO) and its partners in support of pro-poor programmes. Except where otherwise stated, it is licensed for non-commercial purposes under the terms of the Open Government Licence v3.0. K4D cannot be held responsible for errors or any consequences arising from the use of information contained in this report. Any views and opinions expressed do not necessarily reflect those of FCDO, K4D or any other contributing organisation.

(C) Crown copyright 2021.

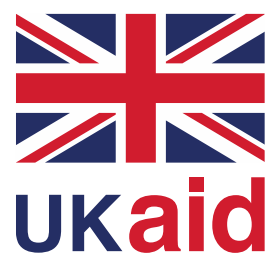

from the British people 